\title{
HPLC ANALYSIS OF AMINO ACIDS CONTENT IN CRAMBE CORDIFOLIA AND CRAMBE KOKTEBELICA LEAVES
}

\section{LIUDMYLA SLOBODIANIUK ${ }^{1}$, LILIIA BUDNIAK ${ }^{2}$, SVITLANA MARCHYSHYN ${ }^{1}$, OLHA SKRYNCHUK ${ }^{3}$, VICTORIIA KUDRIA ${ }^{4}$}

1Department of Pharmacognosy and Medical Botany, I. Horbachevsky Ternopil National Medical University, Maidan Voli 1, 46001, Ternopil, Ukraine, 2Department of Pharmacy Management, Economics and Technology, I. Horbachevsky Ternopil National Medical University, Maidan Voli 1, 46001, Ternopil, Ukraine, ${ }^{3}$ Department of Pharmacy, Bukovinian State Medical University, Theatralna sq. 2, 58002, Chernivtsi, Ukraine, ${ }^{4}$ Department of Pharmacy, National Pirogov Memorial Medical University, Pirogov st. 56, 21000, Vinnytsya, Ukraine Email: stoyko_li@tdmu.edu.ua

Received: 02 Mar 2021, Revised and Accepted: 17 Apr 2021

\section{ABSTRACT}

Objective: The aim of our study was to establish the content of some primary metabolites, such as amino acids in Crambe cordifolia and Crambe koktebelica. The lack of experimental data induced us to determine these compounds.

Methods: Crambe cordifolia and Crambe koktebelica leaves were selected as the objects of the study. The amino acids in the raw materials were determined by the HPLC method.

Results: The results of the research revealed that the leaves of Crambe cordifolia and Crambe koktebelica contain fifteen and sixteen free amino acids respectively. Among the free amino acids L-histidine was presented in Crambe cordifolia leaves in the greatest amount, its content was 12.19 $\mu \mathrm{g} / \mathrm{mg}$. The content of free L-arginine, L-valine, L-phenylalanine, L-isoleucine was the greatest in Crambe koktebelica leaves, it was $2.23 \mu \mathrm{g} / \mathrm{mg}, 2.04$ $\mu \mathrm{g} / \mathrm{mg}, 1.74 \mu \mathrm{g} / \mathrm{mg}, 1.50 \mu \mathrm{g} / \mathrm{mg}$ respectively. The content of bound L-glutamic acid, Glycine, L-arginine, L-leucine was the highest in Crambe cordifolia and Crambe koktebelica leaves.

Conclusion: The results of the study showed that Crambe cordifolia and Crambe koktebelica can be considered as a source of highly digestible amino acids that can be used to treat some diseases.

Keywords: Crambe cordifolia, Crambe koktebelica, Amino acids, HPLC, Leaves

(C) 2021 The Authors. Published by Innovare Academic Sciences Pvt Ltd. This is an open access article under the CC BY license (https://creativecommons.org/licenses/by/4.0/) DOI: https://dx.doi.org/10.22159/ijap.2021v13i4.41265. Journal homepage: https://innovareacademics.in/journals/index.php/ijap

\section{INTRODUCTION}

Medicinal plants are the major natural resources found in the world, in which it contains more active phytoconstituents [1]. Nowadays, plants are recognized as a form of folk remedies due to their wide therapeutic potential and, in turn, minor side effects and good toleration with patients regardless of age [2-4]. The use for the benefit of mankind of medicinal plants (MP) in folk and scientific medicine has a centuriesold tradition $[5,6]$. Medicinal plants play a main role in the development of traditional medicine, as well as actual pharmaceuticals [7-9]. Since 1981, 38 molecules have been derived from medicinal plants, out of which 1,130 new therapeutic agents have approved as pharmaceutical drugs [10]. Herbal remedies are widely used in the complex treatment of various diseases [11]

Crambe L. (Brassicaceae) is the genus of one flowering plants' group with almost 38 species of the Old World, and is the second largest member of the family Brassiceae [12]. These species are annual, biennial or perennial and have different uses, for example, as a source of biofuel (seeds contains up to $60 \%$ of erucic acid), as vegetables or forage plants, in the paint industry, as oilseed, in the food industry for confectionery, in the chemical industry $[13,14]$. The genus Crambe L. has a wide area of spread that goes from Macaronesia to western China and northern India [15]. Species of Crambe genus are very promising in terms of their biochemical and biological properties [16]. A great amount of work has been done upon different species of Crambe in order to evaluate their industrial and pharmaceutical importance [17]. For example, Crambe abissinica is the most known species due to the content of oil and amino acids, protein, phenolic compounds [18]. Also, Crambe abyssinica seed oil contains erucic acid (similar to $59 \%$ of $\mathrm{C} 22: 1$ ) which is an important building material for the oleochemical industry [19]. Crambe orientalis can prevent seed germination and shows phytotoxic effects [20]. The other member of this genus, Crambe cordifolia, is used as livestock feed [17]. It includes a variety of chemical compounds including quercetin and glycosides of kaempferol [18,
21]. Crambe cordifolia is a rich source of polyphenol compounds with antioxidant activity [22]. Normally, it contains quercetin 3feruloylglucoside-7, 4'-diglucoside and kaempferol 3-(p-coumaroyl) glucoside-7, 4'-diglucoside $[17,18,23]$.

But there was a complete gap in the amino acid composition of Crambe cordifolia. Other species, in particular Crambe koktebelica, which is cultivated in Ukraine, has not been studied in chemical and pharmacological aspects. Thus, the aim of our study was to establish the content of some primary metabolites, such as amino acids in Crambe cordifolia and Crambe koktebelica. The lack in experimental data induced us to determine these compounds.

\section{MATERIALS AND METHODS}

\section{Plant materials}

Crambe cordifolia and Crambe koktebelica leaves were selected as the objects of the study. The raw material was provided by the Cultural Flora Department of M. M. Gryshko National Botanic Garden of the National Academy of Sciences of Ukraine. The leaves were collected in summer 2018. The raw material was authenticated by Prof. Dzhamal Rakhmetov. A vouchers specimens of Crambe cordifolia no. 253 and Crambe koktebelica no. 254 are kept at the Department of Pharmacognosy and Medical Botany, TNMU, Ternopil, Ukraine [24]. The study plant material was dried using the conventional method and stored in paper bags in a dry place $[25,26]$.

\section{Chemicals and standards}

Standards of amino acids, including L-glutamic acid (Glu), L-aspartic acid (Asp), L-methionine (Met), L-histidine (His), L-alanine (Ala), Lisoleucine (Ile), L-arginine (Arg), Glycine (Gly), L-valine (Val), Ltyrosine (Tyr), L-serine (Ser), L-cystine (Cys), L-phenylalanine (Phe), L-threonine (Thr), L-lysine (Lys), L-leucine (Leu), L-proline (Pro), obtained from Sigma (Sigma-Aldrich, St. Louis, MO, USA), were of analytical grade ( $>99 \%$ purity) (fig. 1 ). 


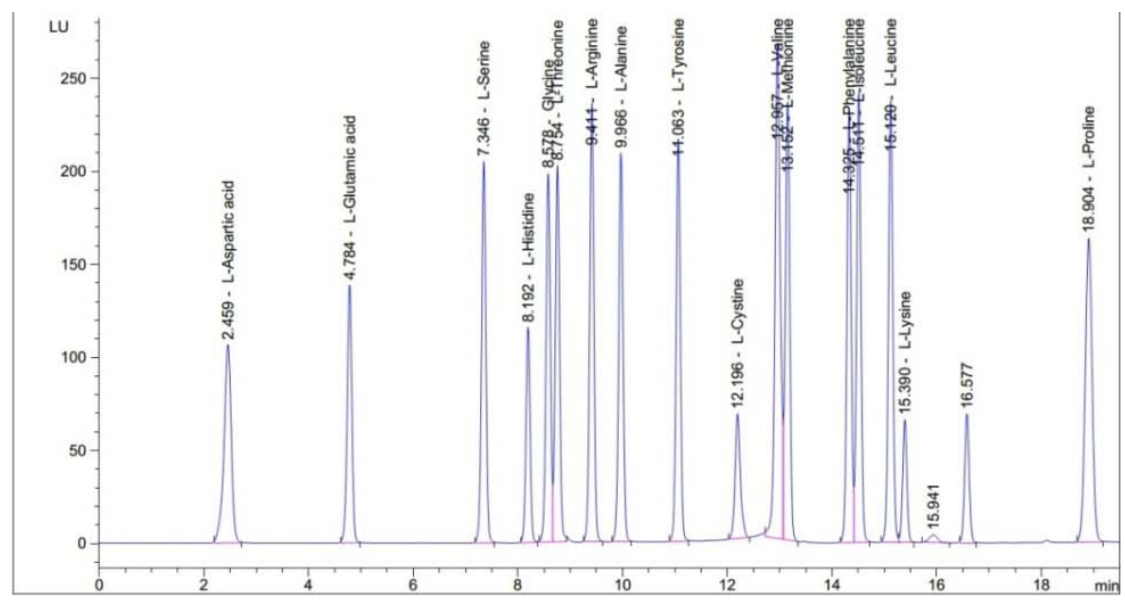

Fig. 1: HPLC chromatogram of amino acids standards

Derivatizing agent's o-phthalaldehyde (OPA) and 9-fluorenylmethyl chloroformate (FMOC) were purchased in Merck. Acetonitrile (ACN) and hydrochloric acid $(\mathrm{HCl})$ were from Sigma-Aldrich Chemical Co. (St. Louis, MO, USA).

\section{HPLC determination of amino acids}

The amino acids composition of Crambe cordifolia and Crambe koktebelica leaves are determined by HPLC method with a precolumn derivatization FMOC ana OPA.

Reference solutions of free amino acids have been made with distilled water at $0.03 \mathrm{M}$ concentrations of each (weighed with analytical accuracy), stored in the refrigerator and further diluted before use, in every second day.

HPLC analysis of amino acids was conducted using Agilent 1200 (Agilent Technologies, USA). Samples were analyzed using a column length Zorbax AAA-150 mm, inner diameter-4.6 mm, the diameter of sorbent grain $3 \mu$ (Hypersil ODS (prepared by BST, Budapest, Hungary)). Mobile phase A-40 mmol $\mathrm{Na}_{2} \mathrm{HPO}_{4}, \mathrm{pH} 7.8$; mobile phase B- $\mathrm{CH}_{3} \mathrm{CN}: \mathrm{CH}_{3} \mathrm{OH}: \mathrm{H}_{2} \mathrm{O}$ (45:45:10, v/v/v). Gradient separation regime with a constant mobile flow rate of $1.5 \mathrm{ml} / \mathrm{min}$. The temperature of the thermostat column is $40^{\circ} \mathrm{C}$.

The pre-column derivatization was conducted with a help of automatic programmable regulations using OPA reagent and FMOC reagent. Identification of derivatized amino acids was done by a fluorescence detector [27-29]. For the extraction of free amino acids of powdered the raw material (to the $131 \mathrm{mg}$ of Crambe cordifolia; to the $133 \mathrm{mg}$ of Crambe koktebelica), put in a test flask, $0.1 \mathrm{~mol} / \mathrm{l}$ water solution of hydrochloric acid was added. The extraction was performed in the ultrasonic water bath at $50^{\circ} \mathrm{C}$ for $3 \mathrm{~h}$. Extraction of bound and free amino acids was performed by adding $2 \mathrm{ml}$ of a water solution of $6 \mathrm{M}$ hydrochloric acid to the powdered of the raw material (to the $132 \mathrm{mg}$ of Crambe cordifolia; to the $134 \mathrm{mg}$ of Crambe koktebelica). Hydrolysis was conducted for $24 \mathrm{~h}$ in a thermostat at $110^{\circ} \mathrm{C}$.

$0.5 \mathrm{ml}$ of centrifuged extract was vaporized on a rotary evaporator and then rinse three times with purified water to eliminate hydrochloric acid. The product received was resuspended in $0.5 \mathrm{ml}$ water and filtered through membrane filters from restored cellulose with pores of $0.2 \mu \mathrm{m}$. Before recording the samples into the chromatographic column in the automatic software mode, fluorescence derivative amino acids were obtained.

Identification of amino acids was performed according to their holdup time (using standards as a reference) at $265 \mathrm{~nm}$. The quantitative content of amino acids is calculated from the value of the peak area of the amino acids.

The number of amino acids in $\mu \mathrm{g} / \mathrm{mg}$ was calculated according to the following equation:

$$
\mathrm{X}=\frac{C \times V}{m},
$$

where: $C$ - concentration, obtained from the chromatogram by calculating the reference solution and the test solution;

$V$ - the volume of solvent for extraction;

$m-$ is a mass of plant material $[30,31]$.

Table 1: The amino acid composition content of Crambe cordifolia and Crambe koktebelica leaves

\begin{tabular}{|c|c|c|c|c|}
\hline \multirow[t]{3}{*}{ Amino acid name } & \multicolumn{4}{|c|}{ Amino acid content, $\mu \mathrm{g} / \mathrm{mg}^{-} \pm \Delta \mathrm{x}^{-}, \mathrm{n}=3, \mathrm{P}<0.05$} \\
\hline & \multicolumn{2}{|c|}{ Crambe cordifolia } & \multicolumn{2}{|c|}{ Crambe koktebelica } \\
\hline & Free & Bound & Free & Bound \\
\hline L-aspartic acid (Asp) & $0.99 \pm 0.03$ & $6.88 \pm 0.04$ & $1.32 \pm 0.02$ & $3.49 \pm 0.05$ \\
\hline L-glutamic acid (Glu) & $0.75 \pm 0.02$ & $14.93 \pm 0.13$ & $0.76 \pm 0.01$ & $7.86 \pm 0.08$ \\
\hline L-serine (Ser) & $1.12 \pm 0.05$ & $7.14 \pm 0.04$ & $0.69 \pm 0.02$ & $3.20 \pm 0.03$ \\
\hline L-histidine (His) ${ }^{*}$ & $12.19 \pm 0.08$ & $1.92 \pm 0.02$ & $1.25 \pm 0.04$ & $2.57 \pm 0.05$ \\
\hline Glycine (Gly) & 0 & $14.75 \pm 0.09$ & $0.35 \pm 0.01$ & $6.57 \pm 0.09$ \\
\hline L-threonine (Thr) & $0.83 \pm 0.02$ & $4.79 \pm 0.05$ & $1.06 \pm 0.01$ & $2.20 \pm 0.03$ \\
\hline L-arginine (Arg) & $0.89 \pm 0.03$ & $11.38 \pm 0.11$ & $2.23 \pm 0.03$ & $6.30 \pm 0.12$ \\
\hline L-alanine (Ala) & $2.16 \pm 0.04$ & $8.94 \pm 0.07$ & $1.15 \pm 0.02$ & $3.42 \pm 0.05$ \\
\hline L-tyrosine (Tyr) & $0.79 \pm 0.01$ & $3.89 \pm 0.06$ & $1.01 \pm 0.01$ & $2.04 \pm 0.02$ \\
\hline L-valine (Val) ${ }^{*}$ & $1.28 \pm 0.05$ & $5.60 \pm 0.10$ & $2.04 \pm 0.04$ & $1.87 \pm 0.03$ \\
\hline L-methionine (Met)* & $0.08 \pm 0.01$ & $1.34 \pm 0.03$ & $0.14 \pm 0.01$ & $0.58 \pm 0.01$ \\
\hline L-phenylalanine (Phe) & $1.08 \pm 0.02$ & $5.40 \pm 0.11$ & $1.74 \pm 0.03$ & $1.89 \pm 0.02$ \\
\hline L-isoleucine (Ile)* & $1.28 \pm 0.04$ & $4.88 \pm 0.08$ & $1.50 \pm 0.02$ & $2.16 \pm 0.04$ \\
\hline L-leucine (Leu) ${ }^{*}$ & $1.13 \pm 0.03$ & $10.73 \pm 0.12$ & $0.96 \pm 0.01$ & $5.08 \pm 0.08$ \\
\hline L-lysine (Lys) ${ }^{* * *}$ & $0.96 \pm 0.01$ & $3.93 \pm 0.09$ & $1.13 \pm 0.05$ & $2.63 \pm 0.02$ \\
\hline L-proline (Pro) & $1.51 \pm 0.02$ & $0.15 \pm 0.01$ & $1.30 \pm 0.03$ & $0.10 \pm 0.01$ \\
\hline
\end{tabular}

Note: Values are mean \pm SEM $(n=3)$, *essential amino acid; * *semi-essential amino acid. 


\section{Statistical analysis}

All analyzes were performed three times. The results were expressed as mean values and standard deviation. Values were determined using Statistica v 10.0 (StatSoft Inc.) program. The level of significance was set at ${ }^{*} \mathrm{p}<0.05$ for all statistical analyses $[32,33]$.

\section{RESULTS AND DISCUSSION}

The amino acid composition of Crambe cordifolia and Crambe koktebelica leaves is in (table 1).

The HPLC method identified in Crambe cordifolia and Crambe koktebelica leaves fifteen and sixteen free amino acids respectively (fig. 2, 3).

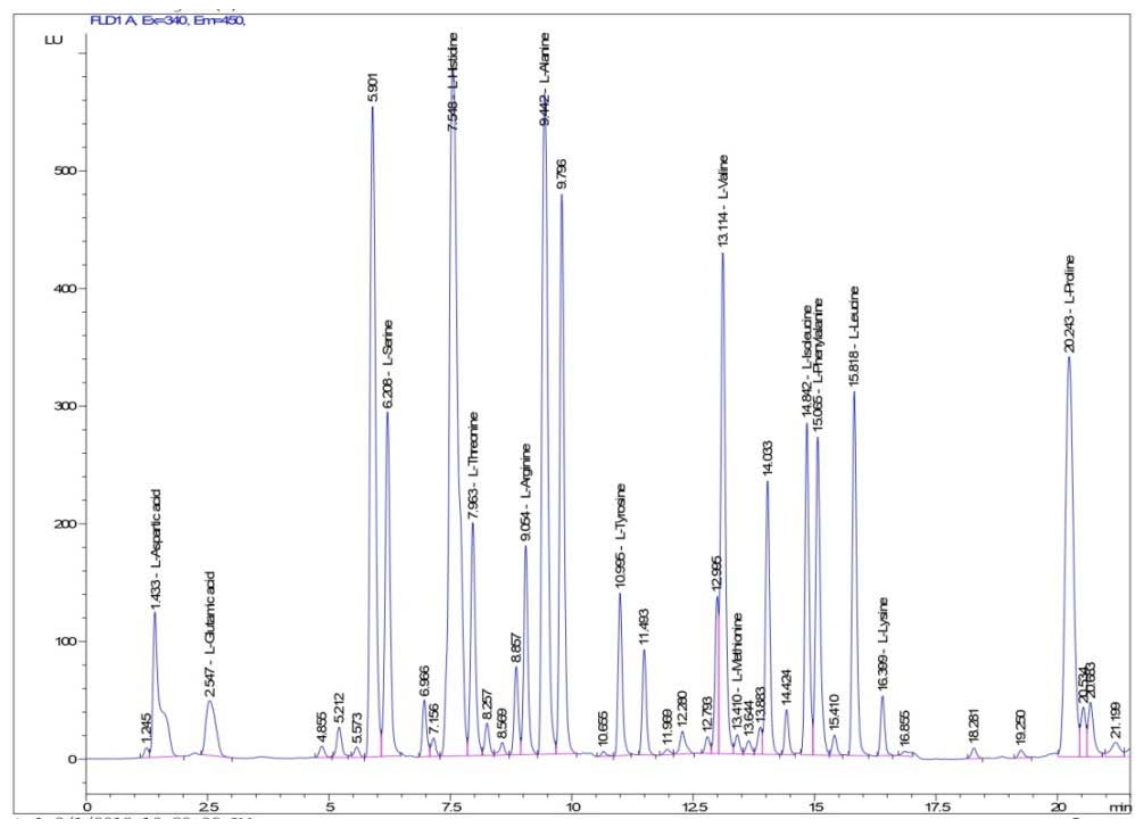

Fig. 2: HPLC chromatogram of Crambe cordifolia free amino acids

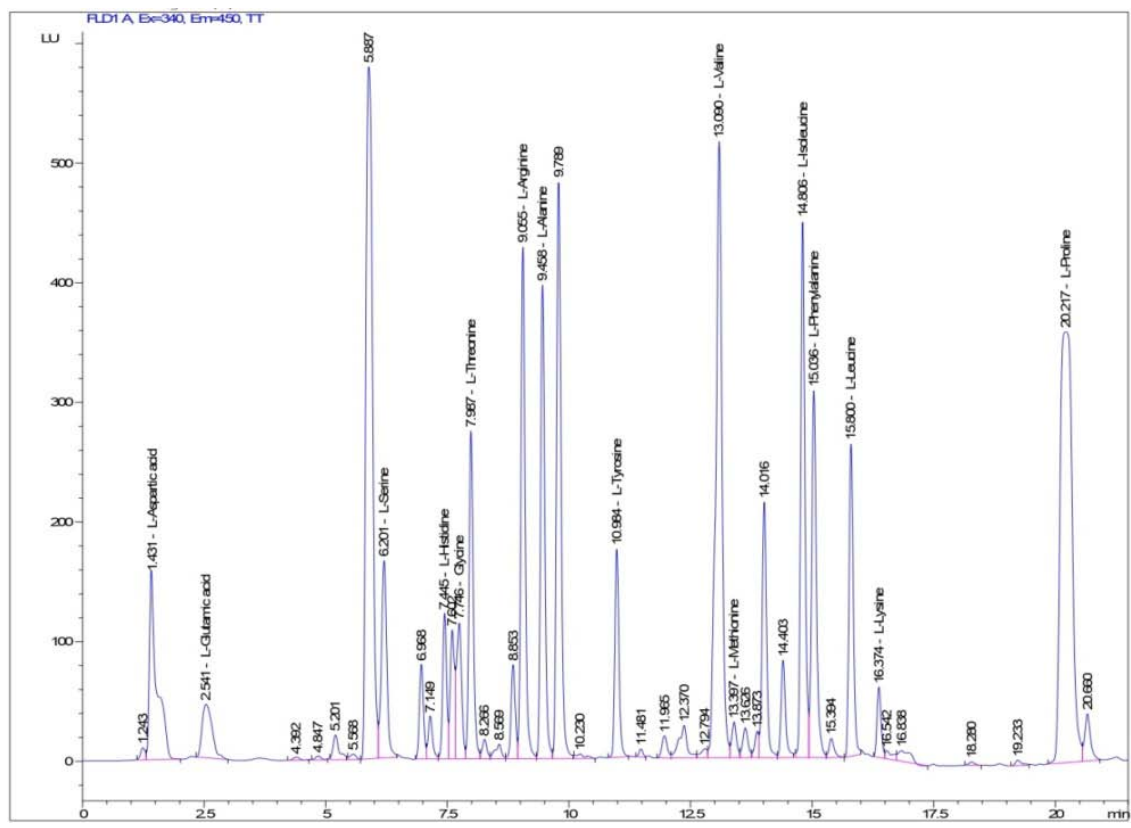

Fig. 3: HPLC chromatogram of Crambe koktebelica free amino acids

L-histidine was presented in Crambe cordifolia leaves in the greatest amount among the free amino acids, its content was $12.19 \mu \mathrm{g} / \mathrm{mg}$. The amino acid L-histidine plays a key role in the cultivation and development of plants [34]. Histidine is an essential amino acid needed in infant nutrition [35]. In addition, this amino acid is a histamine precursor and is effective as a component of solutions used to protect the myocardium and preserve organs [36]. This acid is also a precursor to hormones such as thyrotropin-releasing and metabolites that affect gastric secretion, neurotransmission, renal function, and the immune system [37]. Histidine supplements are effective in plasma lipids, insulin resistance, and inflammatory markers, they delay the development of atherosclerosis in metabolic syndrome and diabetes [38].

The quantitative content of other amino acids was much smaller. Glycine was not found. The content of free L-arginine, L-valine, L- 
phenylalanine, L-isoleucine was the highest in Crambe koktebelica leaves, which was $2.23 \mu \mathrm{g} / \mathrm{mg}, 2.04 \mu \mathrm{g} / \mathrm{mg}, 1.74 \mu \mathrm{g} / \mathrm{mg}$ and 1.50 $\mu \mathrm{g} / \mathrm{mg}$ respectively. L-valine maintains a branched-chain amino acid balance, while alanine is involved in hepatic autophagy, transamination, and gluconeogenesis [28].

L-arginine is a semi-essential amino acid that plays an important role in the cardiovascular system. It is the only substrate for the production of nitric oxide, from which L-arginine has an effect on the cardiovascular system [39]. It is of great importance as an intermediate in the synthesis of urea [40]. The amino acid L-arginine is used by the body in tissue recovery, protein synthesis, and immune cell function [41]. Also, it is extremely needed by young people [28].

L-phenylalanine is essential for humans and can be converted in vivo to tyrosine, which afterwards becomes converted into catecholamine neurotransmitters. Therefore, supplements with this amino acid have antidepressant action [35, 42]. L-phenylalanine is widely used in pharmaceutically active compounds, such as central nervous system neuropeptides, anti-inflammatory remedies, and HIV protease inhibitors [43]. In addition, it is used in food additives, nutraceuticals, aroma, and flavor enhancers, as a building material for medicines, dietary supplements, and ingredients in cosmetics. In particular, L-phenylalanine is used in the production of sweetener aspartame, which has a growing global demand [44].

The amino acid L-isoleucine is of interest as a dietary and nutritional supplement, as well as for enteral and parenteral protein nutrition. It affects the replenishment of the lack of proteins, amino acids, carbohydrates, has an antitoxic effect [45].

Sixteen bound amino acids were found in the raw material of studied species (fig. 4, 5). The quantitative content of all amino acids, except L-histidine, L-valine and L-proline, showed a tendency to increase significantly after hydrolysis.

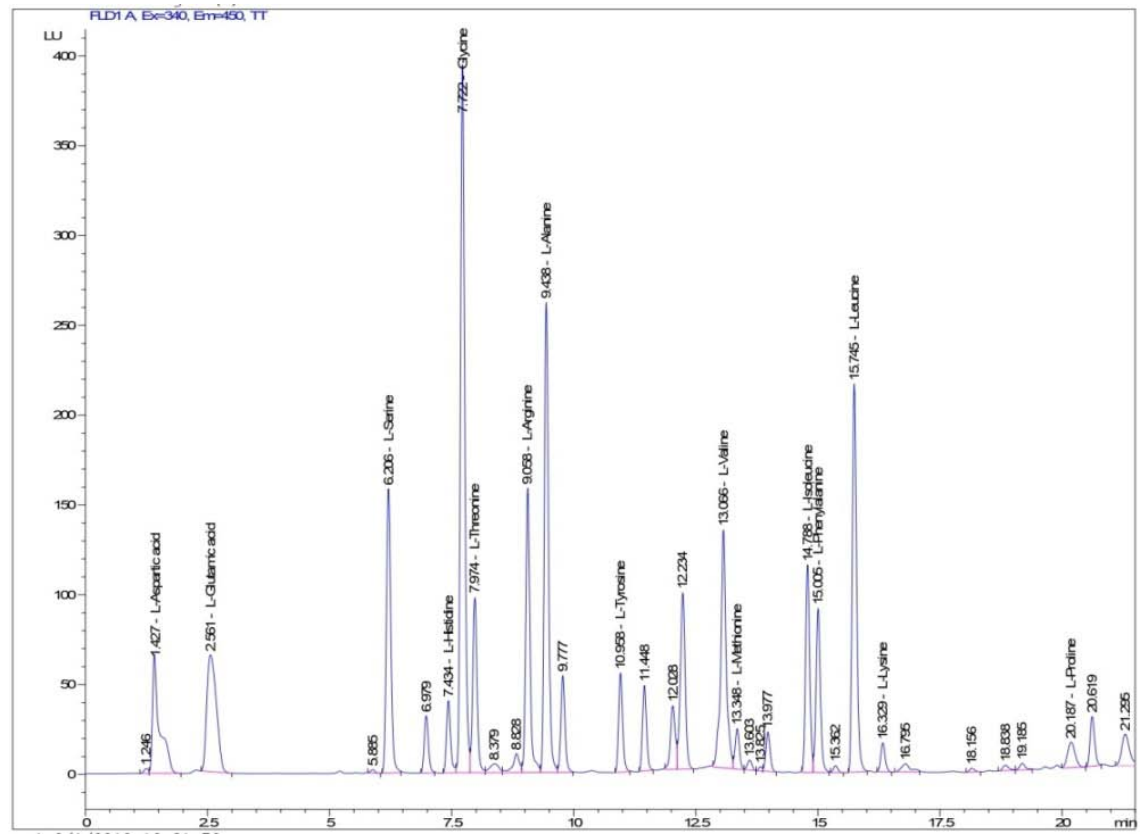

Fig. 4: HPLC chromatogram of Crambe cordifolia bound amino acids

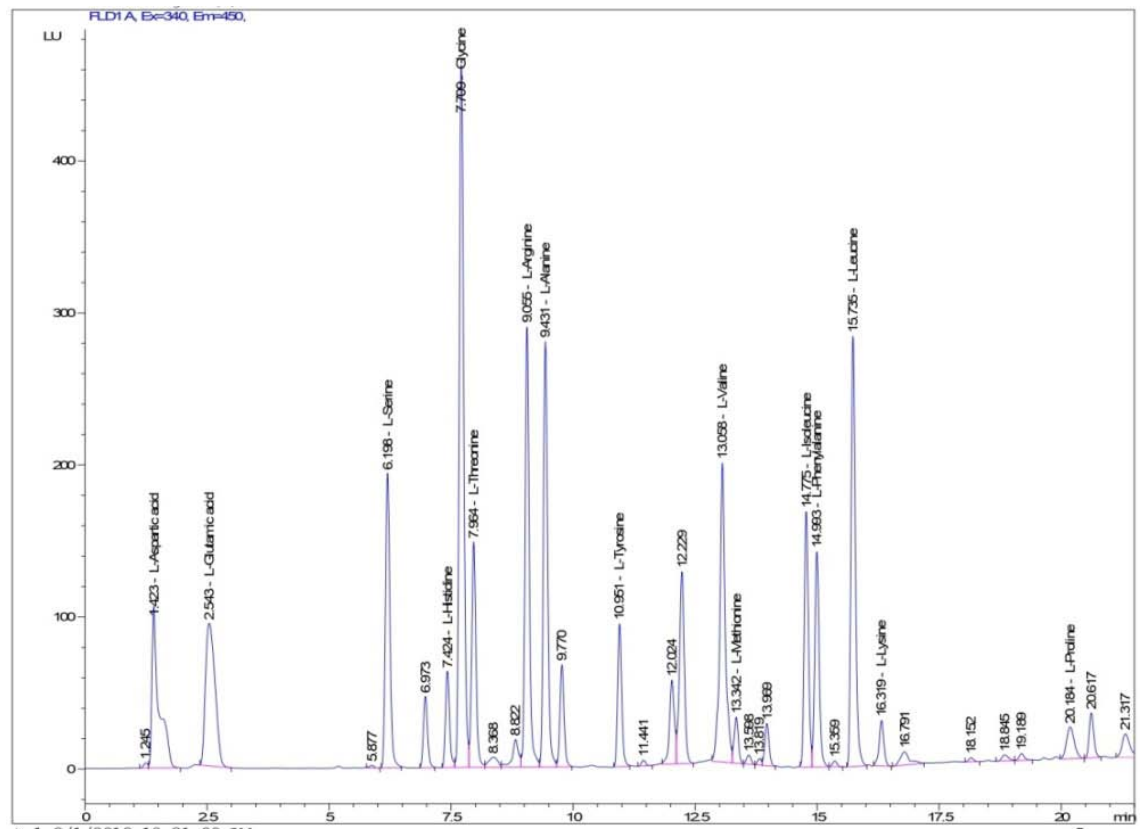

Fig. 5: HPLC chromatogram of Crambe koktebelica bound amino acids 
The content of bound L-glutamic acid, Glycine, L-arginine, L-leucine in Crambe cordifolia and Crambe koktebelica leaves was the highest. Glutamic acid is a source of glucose and participates in a great amount of metabolic reactions. It holds the acidity, the normal blood glucose level and acts as a source of fuel for the intestinal epithelium. Glutamic acid conjugate is able to increase the effectiveness of antitumor drugs and reduce their toxicity to normal cells. Synthetic amides of L-glutamic acid are active against Ehrlich ascites carcinoma $[31,46]$. Glycine is a component of glycocholic and bile acids. It is an essential substrate for the synthesis of several biologically important compounds and biomolecules, such as porphyrin, glucose, purine nucleotides, creatinine, and neurotransmitters. It is involved in detoxification reactions, protein synthesis of glutathione tripeptide. Glycine has an extensive spectrum of immunomodulatory, cytoprotective, and antiinflammatory properties [47]. L-leucine collaborates to energy metabolism, that is fatty acid oxidation, glucose uptake, mitochondrial biogenesis [48]. This amino acid has a significant signaling role in adipose tissue and skeletal muscle, breast epithelial cells, and placental cells [31]. Nevertheless, Glycine was detected only in a bound form in Crambe cordifolia leaves.

\section{CONCLUSION}

This experiment used external standards and high-performance liquid chromatography to determine the amount of amino acids in Crambe cordifolia and Crambe koktebelica leaves. High concentrations of L-glutamic acid, Glycine, L-arginine, L-leucine were predominant in both types of analyzed plants. Concrete metabolic processes in which these amino acids participate may be related to the medicinal properties of plants as per their use in traditional medicine and, thus can alleviate the understanding of their helpful properties.

The specific metabolic processes, in which these amino acids are involved, may be related to the medicinal properties of plants according to their use in traditional medicine. Therefore, they may facilitate the understanding of their beneficial properties.

Thus, Crambe cordifolia and Crambe koktebelica can be considered as a source of highly digestible amino acids that can be used to treat some diseases.

\section{FUNDING}

Nil

\section{AUTHOR CONTRIBUTIONS}

All the authors have contributed equally.

\section{CONFLICTS OF INTERESTS}

The authors declare no conflict of interest.

\section{REFERENCES}

1. Valarmathi R, Natarajan D. Gas chromatography and mass spectrometry analysis of bioactive compounds of Dryopteris hirtipes (Blumze) kuntze. Asian J Pharm Clin Res 2020;13:119-22.

2. Stoiko L, Kurylo K. Development of optimal technology of alcohol extract Centaurium erythraea rafn. Herb. Arch Balk Med Union 2018;53:523-8.

3. Darzuli N, Budniak L, Hroshovyi T. Selected excipients in oral solid dosage form with dry extract of Pyrola rotundifolia L. IJAP 2019;11:210-6.

4. Huzio N, Grytsyk A, Slobodianiuk L. Determination of carbohydrates in Agrimonia eupatoria L. herb. Sci Rise: Pharm Sci 2020;28:35-40.

5. Slobodianiuk L, Budniak L, Marchyshyn S, Basaraba R. Investigation of the hepatoprotective effect of the common cat's foot herb dry extract. Pharmacologyonline 2020;3:310-8.

6. Saeedi R, Sultana A, Rahman K. Medicinal properties of different parts of Acacia nilotica linn (Babul), its phytoconstituents and diverse pharmacological activities. Int J Pharm Pharm Sci 2020;12:8-14.

7. Ahmed N, Mahmood A, Tahir SS, Bano A, Malik RN, Hassan S, et al. Ethnomedicinal knowledge and relative importance of indigenous medicinal plants of Cholistan desert, Punjab Province, Pakistan. J Ethnopharmacol 2014; 155:1263-75.

8. Sevastre B, Sarpataki O, Stan RL, Taulescu M, Sevastre Berghian AC, Olah NK, et al. Anticancer activity of Euonymus europaeus fruits extract on human melanoma cells. Farmacia 2017;65:56-62.

9. Haidan Y, Qianqian M, Li Y, Guangchun P. The traditional medicine and modern medicine from natural products. Molecules 2016;21:559.

10. Kokila NR, Mahesh B, Mruthunjaya K. Exploration of bioactive components of Thunbergia coccinea, its pharmacognostic, antioxidant, GCMS and antihyperglycemic studies. Int J Pharm Pharm Sci 2020;12:45-54.

11. Kurylo K, Budniak L, Volska A, Zablotskyy B, Klishch I. Influence of phytocompositions on dynamics of changes in basal glycemia and glycemia in oral glucose tolerance test in rats with streptozotocin-nicotinamide-induced diabetes mellitus type 2. Georgian Med News 2020;300:112-6.

12. Francisco Ortega J, Fuertes Aguilar J, Gomez Campo C, Santos Guerra A, Jansen RK. Internal transcribed spacer sequence phylogeny of Crambe L. (Brassicaceae): molecular data reveal two old world disjunctions. Mol Phylogenet Evol 1999;11:361-80.

13. Prakhova TYa. New unconventional oilseed-abyssinian Crambe. J Bull ASAU 2013;8:8-10.

14. Pushkarova NO, Kalista MS, Kharkhota MA, Rakhmetov DB, Kuchuk MV. Biotechnological approaches for conservation of the endangered species Crambe koktebelica (Junge) N. Busch and effect of aseptic in vitro cultivation on its biochemical properties. Biotechnol Acta 2016;9:19-27.

15. Prina A. Taxonomic review of the genus "Crambe" sect. "Crambe" (Brassicaceae, Brassiceae). Ann Jard Bot Mad 2009;66:7-24.

16. Kalista MS. Underutilized medicinal species of Crambe L. of the flora of Ukraine. Agrobiodiversity for improving nutrition, health and life quality; 2017;1:216-20.

17. Bukhari SM, Simic N, Siddiqui HL, Ahmad VU. Determination of antioxidant activity of Crambe cordifolia. World Appl Sci J 2013;22:1561-5.

18. Lovatto NM, Goulart FR, Loureiro BB, Speroni CS, Bender ABB, Giacomini SJ, et al. Crambe (Crambe abyssinica) and sunflower (Helianthus annuus) protein concentrates: production methods and nutritional properties for use in fish feed. An Acad Bras Cienc 2017;89:2495-504.

19. Zorn K, Oroz Guinea I, Bornscheuer UT. Strategies for enriching erucic acid from Crambe abyssinica oil by improved Candida antarctica lipase a variants. Process Biochem 2019;79:65-73.

20. Razavi SM, Nejad Ebrahimi S. Chemical composition, allelopatic and cytotoxic effects of essential oils of flowering tops and leaves of Crambe orientalis L. from Iran. Nat Prod Res 2009;23:1492-8.

21. Aguinagalde I, Del Pero Martinez M. The occurrence of acylated flavonol glycosides in the cruciferae. Phytochemistry 1980;21:2875-8.

22. Rashid MA, Akhtar MN, Ashraf A, Nazir S, Ijaz A, Noradila AO, et al. Chemical composition and antioxidant, antimicrobial and haemolytic activities of Crambe cordifolia roots. Farmacia 2018;66:165-71.

23. Marchyshyn S, Slobodianiuk L, Budniak L, Skrynchuk O. Analysis of carboxylic acids of Crambe cordifolia steven. Pharmacia 2021;68:15-21.

24. Husak L, Dakhym I, Marchyshyn S, Nakonechna S. Determination of sugars and fructans content in Stachys sieboldii. IJGP 2018;12:70-4.

25. Budniak L, Slobodianiuk L, Marchyshyn S, Klepach P, Honcharuk Ya. Determination of carbohydrates content in Gentiana cruciata L. by GC/MS method. IJAP 2021;13:124-8.

26. Marchyshyn S, Budniak L, Slobodianiuk L, Ivasiuk I. Determination of carbohydrates and fructans content in Cyperus esculentus L. Pharmacia 2021;68:211-6.

27. Vons B, Tryhubchak O, Grochovuy T, Chubka M, Bihunyak V. Research of powders of the cryolyophilized xenoderm of porcine skin. IJGP 2018;12:657-64.

28. Slobodianiuk L, Budniak L, Marchyshyn S, Basaraba R. Determination of amino acids and sugars content in Antennaria dioica gaertn. IJAP 2019;11:39-43.

29. Hanczko R, Jambor A, Perl A, Molnar Perl I. Advances in the ophthalaldehyde derivatizations: comeback to the 0 - 
phthalaldehydeethanethiol reagent. J Chromatogr A 2007;1163:25-42.

30. Jambor A, Molnar Perl I. Amino acid analysis by highperformance liquid chromatography after derivatization with 9-fluorenylmethyloxycarbonyl chloride literature overview and further study. J Chromatogr A 2009;1216:3064-77.

31. Slobodianiuk L, Budniak L, Marchyshyn S, Sinichenko A, Demydiak 0. Determination of amino acids of cultivated species of the genus Primula L. Biointerface Res Appl Chem 2021;11:8969-77.

32. Budniak L, Slobodianiuk L, Marchyshyn S, Demydiak O. Determination of Arnica foliosa nutt. fatty acids content by GC/MS method. Sci Rise: Pharm Sci 2020;28:14-8.

33. Budniak L, Slobodianiuk L, Marchyshyn S, Kostyshyn L, Horoshko O. Determination of composition of fatty acids in Saponaria officinalis L. Sci Rise: Pharm Sci 2021;29:25-30.

34. Ingle RA. Histidine biosynthesis. Arabidopsis Book; 2011.

35. Belitz HD, Grosch W, Schieberle P. Amino acids, peptides, proteins. In: Belitz HD, Grosch W, Schieberle P. editors. Food Chem. $2^{\text {nd }}$ ed. Berlin: Springer-Verlag; 2009.

36. Moro J, Tome D, Schmidely P, Demersay TC, Azzout Marniche D. Histidine: a systematic review on metabolism and physiological effects in human and different animal species. Nutrients 2020;12:1414.

37. Kessler AT, Raja A. Biochemistry, histidine. In: Stat Pearls. Treasure Island (FL): StatPearls Publishing; 2020.

38. Holecek M. Histidine in health and disease: metabolism, physiological importance, and use as a supplement. Nutrients 2020;12:848.
39. Sudar Milovanovic E, Obradovic M, Jovanovic A. Benefits of Larginine on cardiovascular system. Mini Rev Med Chem 2016;16:94-103.

40. Belitz HD, Grosch W, Schieberle P. Food chemistry. Berlin, Heidelberg: Springer; 2009.

41. Pahlavani N, Jafari M, Sadeghi O, Rezaei M, Rasad H, Rahdaret $\mathrm{HA}$, et al. L-arginine supplementation and risk factors of cardiovascular diseases in healthy men: a double-blind randomized clinical trial. F1000Research 2017;3:306.

42. Kapalka GM. Practical resources for the mental health professional. Nutritional and herbal therapies for children and adolescents: A handbook for mental health clinicians. Elsevier Academic Press; 2010.

43. Liu Y, Xu Y, Ding D, Wen J, Zhu B, Zhang D. Genetic engineering of Escherichia coli to improve L-phenylalanine production. BMC Biotechnol 2018;18:5.

44. Ding D, Liu Y, Xu Y, Zheng P, Li H, Zhang D, et al. Improving the production of l-phenylalanine by identifying key enzymes through multi-enzyme reaction system in vitro. Sci Rep 2016;6:32208.

45. Sanchez S, Demain AL. Fermentation (industrial) | Production of amino acids. In: Batt CA, Tortorello ML. editors. Encyclopedia of Food Microbiology. 2nd ed. Academic Press; 2014.

46. Dutta S, Ray S, Nagarajan K. Glutamic acid as anticancer agent. Saudi Pharm J 2013;21:337-43.

47. Perez Torres I, Maria Zuniga Munoz A, Guarner Lans V. Beneficial effects of the amino acid glycine. Mini Rev Med Chem 2017;17:15-32

48. Duan Y, Li F, Li Y, Tang Y, Kong X, Feng Z, et al. The role of leucine and its metabolites in protein and energy metabolism. Amino Acids 2016;48:41-51. 